\title{
Scale development in fish: a review, with description of sonic hedgehog (shh) expression in the zebrafish (Danio rerio)
}

\author{
JEAN-YVES SIRE*,1 and MARIE-ANDRÉE AKIMENKO ${ }^{2}$ \\ ${ }^{1}$ Equipe "Evolution et Développement du Squelette", Université Paris 6 - Pierre \& Marie Curie, Paris, France and \\ ${ }^{2}$ Ottawa Health Research Institute, Ottawa, Ontario, Canada
}

\begin{abstract}
In the first part of this paper we review current knowledge regarding fish scales, focusing on elasmoid scales, the only type found in two model species, the zebrafish and the medaka. After reviewing the structure of scales and their evolutionary origin, we describe the formation of the squamation pattern. The regularity of this process suggests a pre-patterning of the skin before scale initiation. We then summarise the dynamics of scale development on the basis of morphological observations. In the absence of molecular data, these observations support the existence of genetic cascades involved in the control of scale development. In the second part of this paper, we illustrate the potential that scale development offers as a model to study organogenesis mediated by epithelial-mesenchymal interactions. Using the zebrafish (Danio rerio), we have combined alizarin red staining, light and transmission electron microscopy and in situ hybridisation using an anti-sense RNA probe for the sonic hedgehog (shh) gene. Scales develop late in ontogeny (30 days post-fertilisation) and close to the epidermal cover. Only cells of the basal epidermal layer express shh. Transcripts are first detected after the scale papillae have formed. Thus, shh is not involved in the mechanisms controlling squamation patterning and scale initiation. As the scales enlarge, shh expression is progressively restricted to a subset of basal epidermal cells located in the region that overlies their posterior field. This pattern of expression suggests that shh may be involved in the control of scale morphogenesis and differentiation in relationship with the formation of the epidermal fold in the posterior region.
\end{abstract}

KEY WORDS: development, scale, shh, zebrafish

\section{Introduction}

In contrast to the considerable knowledge of skin patterning and epithelial appendage development in mammals and birds (for a review: Chuong, 1998), only little is known about the molecular control of skin patterning and scale morphogenesis in "fish"1. Scale formation is, however, well studied at the tissue and cellular level (Sire and Géraudie, 1983; Sire et al., 1997a, 1997b). These data are useful to infer homology of the fish scale by comparing its development with that of other elements of the dermal skeleton. This has proven to be essential for understanding the evolution of the dermal skeleton (Huysseune and Sire, 1998; Sire and Huysseune, 2003). The results of these comparative studies have led to the elaboration of a scenario for the evolution of the various elements of the dermal skeleton from a common ancestral element, the odontode (Reif, 1982; Huysseune and Sire, 1998;

\footnotetext{
${ }^{1}$ In this paper we use " fish " to group all aquatic, non tetrapod vertebrates that possess "scales ", i.e., chondrichthyans (sharks, skates and rays), actinopterygians (ray-finned fish) and basal sarcopterygians (lungfishes and coelacanths).
}

Sire and Huysseune, 2003). However, hypotheses remain to be tested, by using the numerous molecular tools that are now available.

Molecular data on scale development are rare, possibly for two reasons. First, most efforts of geneticists and developmental biologists have concentrated on mouse and chick skin, two models that are more appropriate, as terrestrial animals, for experimental and applied studies than the specialised skin of fish. Second, the scales form only late in ontogeny (several weeks post-fertilisation).

The zebrafish scale should be a good model because nearly all of the regulatory genes, known to control feather, hair and tooth patterning and induction in birds and mammals, have been cloned in this model animal. Whereas the late development of scales in ontogeny appears, at first glance, as a disadvantage (for instance to trace the embryonic origin of the scale-forming cells), it also offers advantages, especially when considering the initiation of the squamation pattern and scale development. Indeed, the developmental processes - including epidermal-dermal interactions, cell proliferation and differentiation - occur within a short

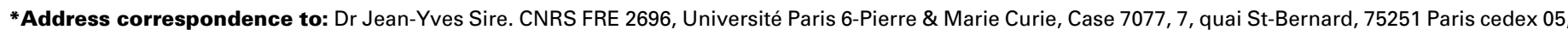
France. Fax: +33-1-4427-5653. email: sire@ccr.jussieu.fr
} 
A
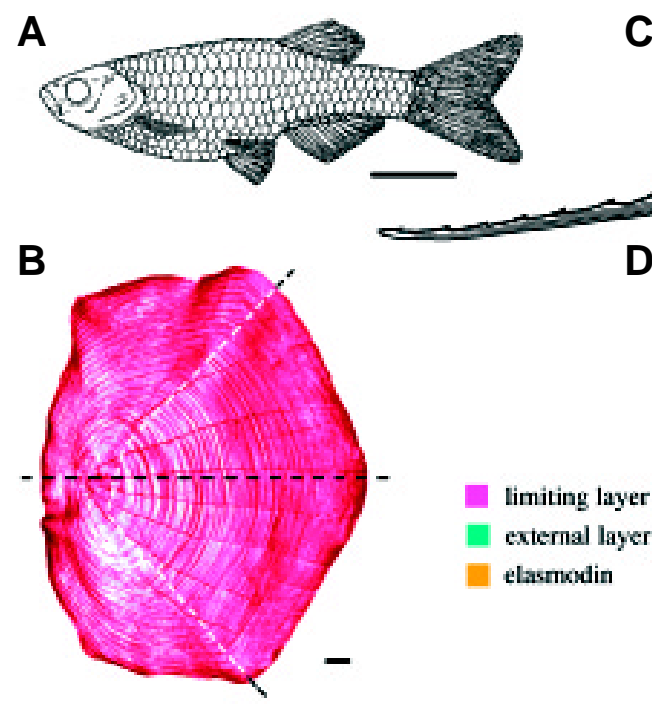

C

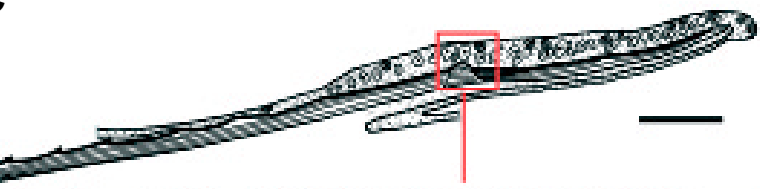

D

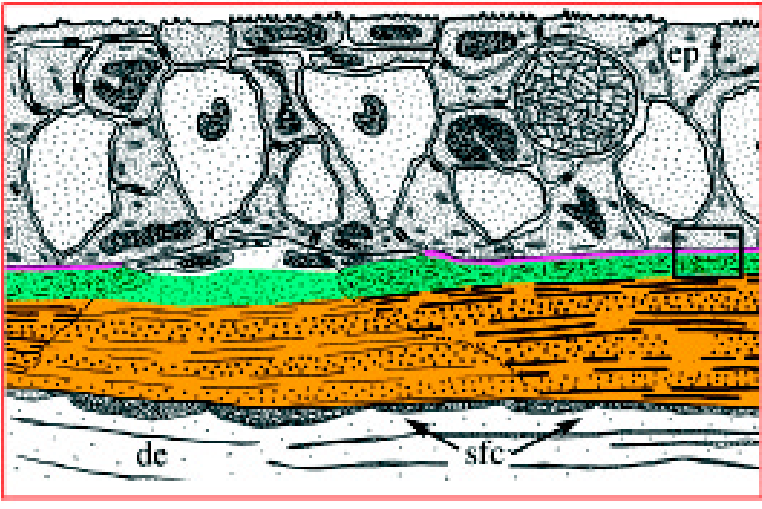

Fig. 1. The adult zebrafish (Danio rerio). (A) Scale pattern. (B) Isolated scale stained with alizarin red. The epidermis covers most of the scale surface; the dotted white line indicates the anterior limit of the epidermal cover. Note the numerous concentric ridges and the radially-arranged grooves in the posterior region. The dotted black line indicates the section level in (C).

(C) Longitudinally-sectioned scale showing its relation with the neighbouring tissues, and especially the epidermal cover.(D) Detail of the boxed area in (C) illustrating the various components of the scale. Note the close relationship between the basal epidermal cells and the scale surface. The section passes through a radius, i.e., an unmineralised region of the scale, that is delimited on both sides by dotted lines. The boxed region in (D) is shown in detail in Fig. 3F. Anterior to the left. de, dermal stroma; ep, epidermis; sfc, scale-forming cells. Scale bars: A, $0.5 \mathrm{~cm} ; B, C, 100 \mu \mathrm{m}$. period and in large individuals compared to the embryos. Preliminary studies have shown that a number of genes known to be involved in the control of organogenesis are expressed during scale development (Sire, unpublished data; and see the second part of this paper).

In the first part of this paper we briefly review the current knowledge on scale development in fish with particular attention for questions that need to be addressed in the near future. In the second part, we describe the expression pattern of sonic hedgehog during scale development in the zebrafish to test whether or not the mechanisms controlling organogenesis through epithelial-mesenchymal interactions could be generalised in vertebrates.

\section{An overview of scale structure, evolution and develop- ment in fish}

\section{What are "scales"?}

Confusingly, the word " scales " is used to refer both to superficial epidermis-derived appendages in sauropsids, covering the body of reptiles and the legs of most birds, and to dermis-derived structures located within the fish skin. Although both types of scales are distributed over the body surface in an orderly pattern, their morphology, their tissue and evolutionary origins are distinct.

In fish literature, the term " scale " is often used as a generalised term for all the hard, generally flattened, skeletal elements found in the skin of aquatic vertebrates. These include the scales of chondrichthyans (placoid scales), the scales of basal actinopterygians (ganoid scales), the bony scales of some actinopterygian taxa (dermal bony scales and scutes) and the scales of basal sarcopterygian taxa and most actinopterygian species (elasmoid scales). Although all these types of appendages are evolutionary linked as derivatives of a common ancestral type (reviews in Huysseune and Sire, 1998; Sire and Huysseune, 2003), they have a different structure (definitions in Francillon-
Vieillot et al., 1990; Zylberberg et al., 1992). Therefore, when referring to scales, the type of scale studied should be specified. Most scales in teleosts, such as, e.g., tilapia (cichlid), trout (salmonid), medaka (cyprinodontid) and zebrafish and carp (cyprinids), belong to the elasmoid type, which is a highly derived type of scale.

Adding to the confusion, some elements called "scales" have a structure closer to teeth than to any other scale type. This is the case for placoid scales, the dermal elements covering the body in chondrichthyans (term coined by Agassiz (1844) and Williamson (1849)). In a recent developmental comparative study of the dermal skeleton, Sire and Huysseune (2003) have proposed the term "odontode" to replace "placoid scale". Indeed, odontodes, which were present in some early vertebrates, 500 million years ago, and which are considered the likely ancestors of all the elements of the dermal skeleton (including teeth) in living vertebrates, have a tooth-like structure (Reif, 1982; Reif and Richter, 2001). Chondrichthyans are the only lineage having conserved odontodes in a nearly unchanged form. In contrast, in the osteichthyan lineage, the odontodes have been progressively modified into various types of "scales", including ganoid scales, dermal bony scales and elasmoid scales. Given their "dental" structure, the "placoid scales" must be distinguished from the other scale types (Sire, 2001; Sire and Huysseune, 2003). "Dermal denticles", a term often used in shark literature, can also be accepted, but is less informative from an evolutionary perspective.

In the present paper, we will focus our attention exclusively on elasmoid scale development, the scale type of zebrafish and medaka, the two vertebrate models for molecular studies.

\section{Structure of the elasmoid scale and its evolutionary origin Scale structure}

The elasmoid scale is the commonest type of scale (most of the 26,000 teleost species possess elasmoid scales). In medaka and zebrafish, the body is covered by several hundreds of large 
elasmoid scales, arranged in longitudinal and vertical rows, forming a regular pattern (Fig. 1A). The elasmoid scale, like the other elements of the dermal skeleton (including the so-called membrane bones), forms in the dermis without the presence of a cartilaginous initium (definitions in Francillon-Vieillot et al., 1990; Zylberberg et al., 1992). They are ornamented, thin, lamellar, collagenous plates located within the upper region of the dermis, close to the epidermis (Fig. 1 B,C).

The elasmoid scale structure has been described in several species belonging to the actinopterygian and the sarcopterygian lineages (see Meunier, 1983; Sire, 1987; Huysseune and Sire, 1998 for a covering of the literature on this topic). In all these species, the elasmoid scales were found to be invariably composed of three tissues, i.e., from the deep face upwards (Fig. 1D): (1) the basal plate, a thick layer of incompletely mineralised tissue composed of elasmodin (previously called isopedin), itself consisting of several layers of collagen fibrils organised into a plywood-like structure (Meunier, 1983; Schultze, 1996); (2) the external layer, a thin layer of well-mineralised tissue composed of a network of interwoven collagen fibrils; (3) the limiting layer, a hyper-mineralised tissue devoid of collagen fibrils and deposited at the scale surface in the region close to the epidermis. The structure and organisation of this upper layer is the most variable amongst the various species (Sire, 1985, 1988; Sire etal., 1997a). During scale development, these three tissues are deposited following an invariable sequence: first the external layer (allowing an extension in diameter), followed by the basal plate (allowing an extension in thickness) and finally the limiting layer. The latter improves scale protection and its anchoring to the epidermis. Separately, these three tissues present structural similarities with the typical dental and skeletal vertebrate tissues (enamel, dentin and attachment tissue, and cartilage and bone). Elasmodin resembles either orthodentin or lamellar bone, the external layer looks like mantle dentin or woven-fibered bone, and the limiting layer is structurally closer to enamel (or ganoine) than to any other known skeletal tissue. Based on structural comparison alone, it is difficult to determine from which tissue (dental or skeletal) the tissues of the elasmoid scale are derived.

\section{Evolutionary origin of the elasmoid scale}

In the scenario proposed by Sire and Huysseune (2003), elasmoid scales are thought to be derived from the superficial "dental" (odontodal would be a more appropriate term) tissues, which covered the rhombic scales in ancestral osteichthyan fish. Luckily, such scales are still present nowadays in the form of ganoid scales in polypterid fishes (Sire et al., 1987; Sire, 1990) (Fig. 2 A-D). The main arguments to support such an evolutionary relationship are that both scales develop close to the epidermal-dermal junction, and that they show a developmental sequence similar to that known for teeth (Thesleff et al., 1995a). This interpretation contrasts with some views claiming that the tissues composing the elasmoid scale are derived from the basal, bony plate of the ancestral rhombic scale (e.g., Schultze, 1966; Meunier, 1983). However, the latter hypothesis is based on a comparison of adult scale structure only, and does not explain the origin of the limiting layer. Topographically, the upper limiting layer, which is devoid of collagen, should be considered as being derived from the upper layer, the ganoine (enamel), of the ancestral rhombic scale. The layers below, the external layer and the elasmodin, should be considered to be derived from the layers located below the enamel, i.e., either two types of dentin (e.g., mantle dentin and orthodentin) or dentin and attachment tissue, respectively (Fig. 2F) (Sire and Huysseune, 2003).

The hypothesis that the limiting layer could be homologous to ganoine is supported by the developmental origin of this tissue. In a cichlid (Hemichromis bimaculatus) and in the zebrafish the developmental sequences strongly suggest that the cells of the basal epidermal layer are involved in the deposition of the limiting layer, i.e. that this tissue could contain epidermal (i.e., enamellike) products (Sire, 1988; Sire etal., 1997a) (Fig. 3). Interestingly, amelogenin, an enamel-specific protein, has been detected immunocytochemically in the developing ganoine of polypterid scales (Zylberberg et al., 1997).

Although the structural and developmental studies strongly support a dental origin for the different tissues in the elasmoid scale, the only convincing evidence would be the demonstration

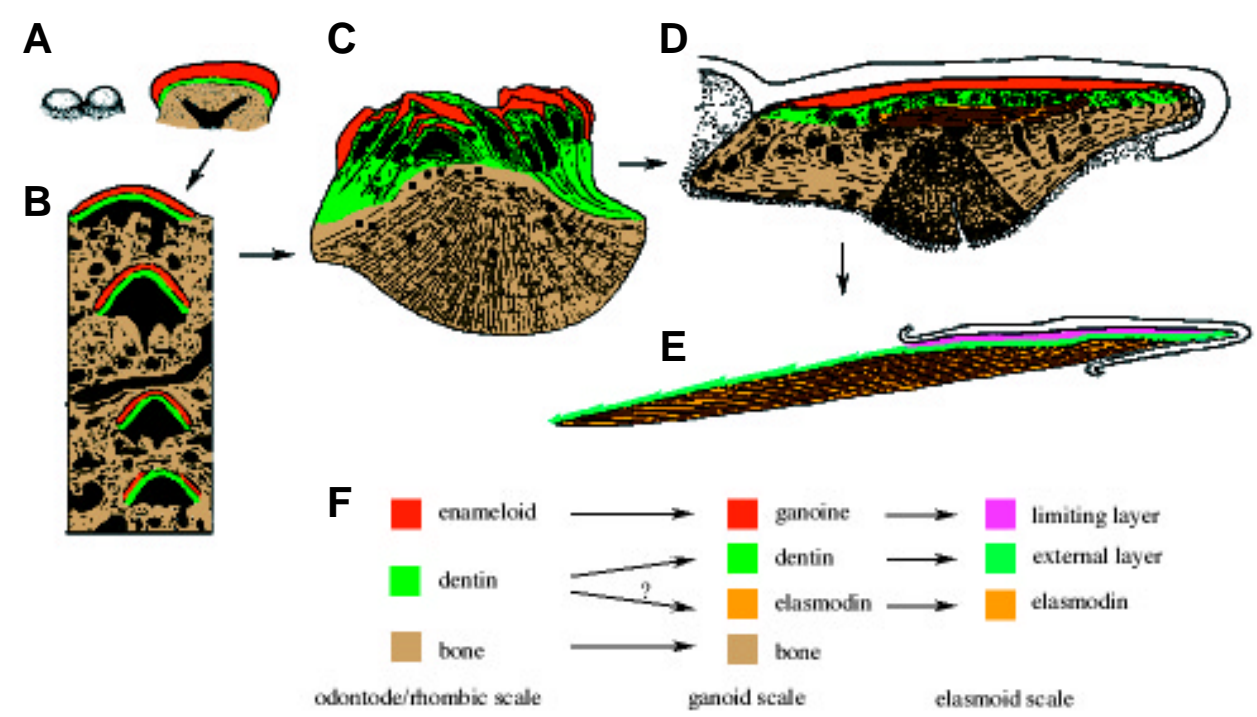

Fig. 2. Currently proposed scenario for the evolutionary origin of the elasmoid scales from ancestral odontodes. (after Huysseune and Sire, 1998; Sire and Huysseune, 2003). (A) Odontodes located at the surface of bony plates covering the body of an astraspid, Pycnaspis (Ordovician, 450 million years ago). These ancestral elements are composed of enamel, dentin and a type of acellular bone, aspidin. (B) Superimposed odontodes surrounded by bony tissue, in a dermal bone of the sarcopterygian Glyptolepis (Devonian). (C) Rhombic scale of one of the earliest actinopterygians, Cheirolepis (380 mya). The upper region is characterized by the close superimposition of odontodes forming an odontocomplex. (D) Ganoid scale of a living polypterid, Polypterus senegalus. This type of scale has conserved numerous characters of the ancestral rhombic scale, notably the odontocomplex constituting its upper surface. It is composed of ganoine (enamel), dentin and a novel tissue, elasmodin. (E) Elasmoid scale as found in the zebrafish. Not drawn to scale. (F) Evolutionary relationships between the various tissues composing the elements of the dermal skeleton described above. 

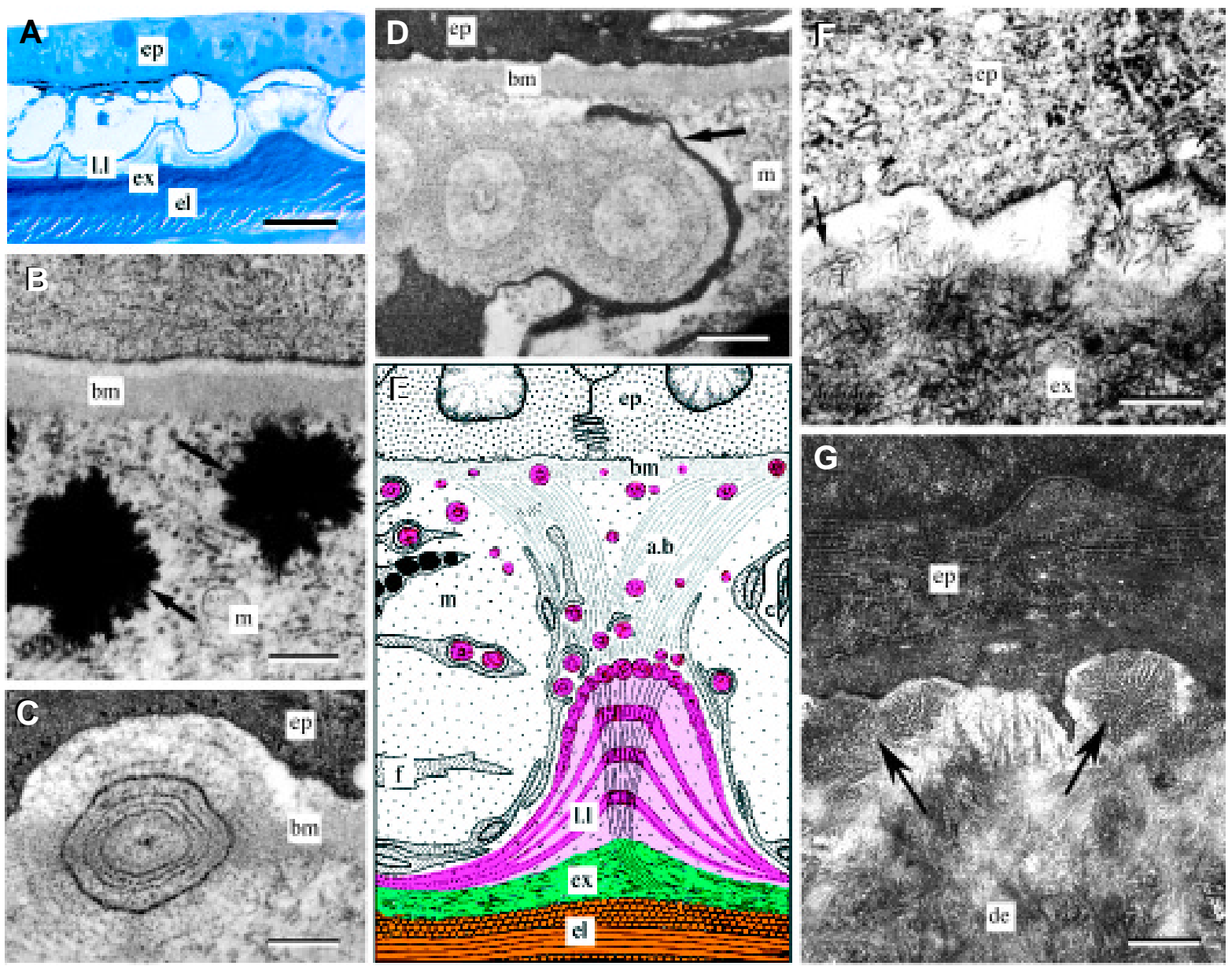

Fig. 3. Epidermal participation to the upper scale layer. (A) One $\mu$ m-thick longitudinal section through the posterior region of a scale in the cichlid Hemichromis bimaculatus (toluidine blue stained). EDTA decalcified scale showing the structure of its upper region, especially the limiting layer, which is devoid of collagen matrix. Anchoring bundles of collagen fibrils link the surface of the limiting layer to the basement membrane underlying the deep surface of the epidermis. (B,C,D) Transmission electron micrographs (TEM) of mineralised spherules (arrows in B) located between the deep surface of the epidermis, within the basement membrane, and at the scale surface, in the cichlid $\mathrm{H}$. bimaculatus. (C,D) Decalcified samples. In (D), the arrow points to a cytoplasmic extension surrounding a spherule. (E) Interpretative drawing of the upper region of the skin in $\mathrm{H}$. bimaculatus. Mineralised spherules are formed by the accumulation of substances probably synthesized by the epidermal basal cells. These spherules reach the scale surface, where they are incorporated in the limiting layer. They either migrate passively within the anchoring collagen bundles or are actively transported by fibroblast-like cells. (F) Section through the upper layer of the posterior region of a zebrafish scale (TEM). Non-decalcified sample. The limiting layer is lined by epidermal basal cells and no basement membrane is visible in between. Small, mineralised, urchin-like spherules are visible at the epidermisscale interface (arrows). (G) Section through the upper layer of the ganoid scale of Polypterus senegalus where ganoine (enamel) is being deposited. Urchin-like patches of ganoine (arrows), looking like mineralised spherules, are deposited at the scale surface by the epidermal basal cells. Bars: $A$, 25 $\mu \mathrm{m} ; B, C, F, 250 \mathrm{~nm} ; D, G, 500 \mathrm{~nm}$. Abbreviations: a.b, anchoring bundle; bm, basement membrane; de, dentin; el, elasmodin; ep, epidermis; ex, external layer; f, fibroblast; I.I, limiting layer; $m$, mesenchyme.

of tooth-specific molecules in the scale tissues. Recent progress in sequencing the zebrafish and medaka genomes should allow to check for the presence of genes encoding dental proteins, in particular amelogenin and dentin sialophosphoprotein (DSPP), known to be highly expressed during enamel and dentin formation, respectively. The presence of amelogenin transcripts in the basal epidermal cells covering the scale surface, and of DSPP mRNAs in the scale-forming cells, would definitely demonstrate the homology of the limiting layer with enamel and the other layers with dentin tissues. So far the amelogenin gene has only been identified in tetrapods, i.e., amphibians, reptiles and mammals (Toyosawa et al., 1998; Ishiyama et al., 1998; Delgado, 2002).
However, immunohistochemical detection of amelogenin-like epitopes in the tooth matrix in other vertebrate lineages (chondrichthyans and actinopterygians) could mean that this protein was present in vertebrate ancestors (Herold et al., 1989). This finding is supported by a recent molecular study indicating a possible origin of the amelogenin 600 millions years ago, long before the first mineralised vertebrate skeletons were recorded in the fossils (Delgado et al., 2001).

\section{Elasmoid scale development}

So far, there are no reports on gene expression during skin development (see also Le Guellec et al., 2004). However, mor- 
phological data suggest that the skin is already pre-patterned at the onset of scale initiation.

\section{Squamation pattern}

The establishment of the squamation pattern has been described in several teleost species (see Sire and Arnulf, 1991), and in some extinct osteichthyans, such as acanthodians (Watson, 1937; Zidek, 1985) and palaeonisciforms (Schultze and Bardak, 1987). From these descriptions we can deduce the following:

1- In all fish species studied so far, the scales appear very late in ontogeny, i.e., after metamorphosis, when the juveniles are already miniatures of the adults. Such a delayed formation was also reported for the dermal bony scales and scutes, as in, e.g., armoured catfish (Sire, 1993). In the zebrafish skin, fibroblasts, from which the scale-forming cells will differentiate, invade the primary dermal stroma only 20-26 days post-fertilisation (Le Guellec et al., 2004; see also Sire et al., 1997a), suggesting that fibroblast invasion (and further skin development) requires a specific state of differentiation of the collagenous stroma, and of the cells of the basal epidermal layer. Indeed, during the previous stages of skin development, the latter are involved in collagen synthesis of the primary dermal stroma (Le Guellec et al., 2004).

2- Although both appear late, the odontode pattern in sharks and the elasmoid scale pattern in bony fishes (= osteichthyans) are established in different ways. In sharks, a large number of odontodes form simultaneously within a given region, and they are randomly arranged (Reif, 1980a; Sire, unpublished data). This condition is, however, restricted to the chondrichthyan lineage. In osteichthyans, a single scale first appears as an "initiator"; scales are next added rapidly and successively in regular rows, to finally constitute the squamation pattern (see below) (Fig. 4A).

3- In most osteichthyan taxa, including the zebrafish (Sire et al., 1997a), the first scales to appear are those of the midline row, at the level of the caudal peduncle, followed by a rapid extension of the squamation anteriorly and posteriorly along this row, while new rows are added dorsally and ventrally (Fig. $4 \mathrm{~A})$. The correlation between the place where the first scale is induced, and the nearby presence of the lateral line, could lead to infer a possible influence of the nervous system in the first "initiator" locus. Indeed, most of the first midline scales rapidly specialise as lateral-line scales, protecting the neuromasts. However, in some species the location of the first "initiator" scale does not conform to this rule. Scales can indeed start to form either in the anterior region (as, e.g., in some cyprinids: McCrimmon and Swee, 1967) or in the region close to the pectoral fin base (as, e.g., in some percids: Cooper, 1971). Remarkably, as already reported in chicken by Sengel (1976), the squamation extends from posterior to anterior, while in general the differentiation processes spread from anterior to posterior. Epigenetic factors (e.g., tensions acting on the skin during swimming) have been suggested to be responsible for the start of scale development in a specific locus (that is, provided the skin has reached an appropriate state of development) (Sire and Arnulf, 1991; and see below).

Alizarin red staining of juvenile zebrafish has revealed that scale appearance is neither related to size nor to age alone, but to a combination of both (Sire et al., 1997a). For instance, reproducible stages of early squamation development can only be found in $30 \mathrm{dpf}, 8.5-\mathrm{mm}$ standard length (SL) specimens. At $30 \mathrm{dpf}$, all specimens larger than $9.5 \mathrm{~mm}$ SL possess scales. At $25 \mathrm{dpf}$, however, $9.0 \mathrm{~mm}$ SL zebrafish have not started scale formation yet (Sire et al., 1997a). The successive appearance of scales allows the study of different stages of scale development in a single individual, from a stage before scale initiation (in the anterior region) to a stage with well formed scales (in the region of the caudal peduncle). The developing scales are first juxtaposed but they rapidly enlarge in diameter, and progressively overlap as roof tiles (Fig. 4B). In one row, the posterior region of a scale covers the anterior region of the following scale, and part of the lateral region of the scales from the two adjacent rows.

Scales develop in the centre of a well-delimited zone corresponding to a square on a chessboard pattern displayed on the body surface (Fig. 4A). This suggests that the dermal stroma of the skin is already patterned (i.e., compartmentalised) when the scales are initiated. This contrasts with the establishment of the odontode pattern in sharks, which suggests that the skin is not pre-patterned and that the pattern is self-organising, probably through the effect of random interaction between epidermis and mesenchyme, in the manner described by Turing (1952) (see Reif, 1980b). In teleost, the skin compartmentalisation is probably related to the complex arrangement of the muscle fibres and myosepta located below the dermis. The helical muscle fibres are arranged into an arch-like architecture and are intersected by numerous myoseptal tendons (composed of collagen bundles). These tendons are firmly attached at specific sites in the dermis

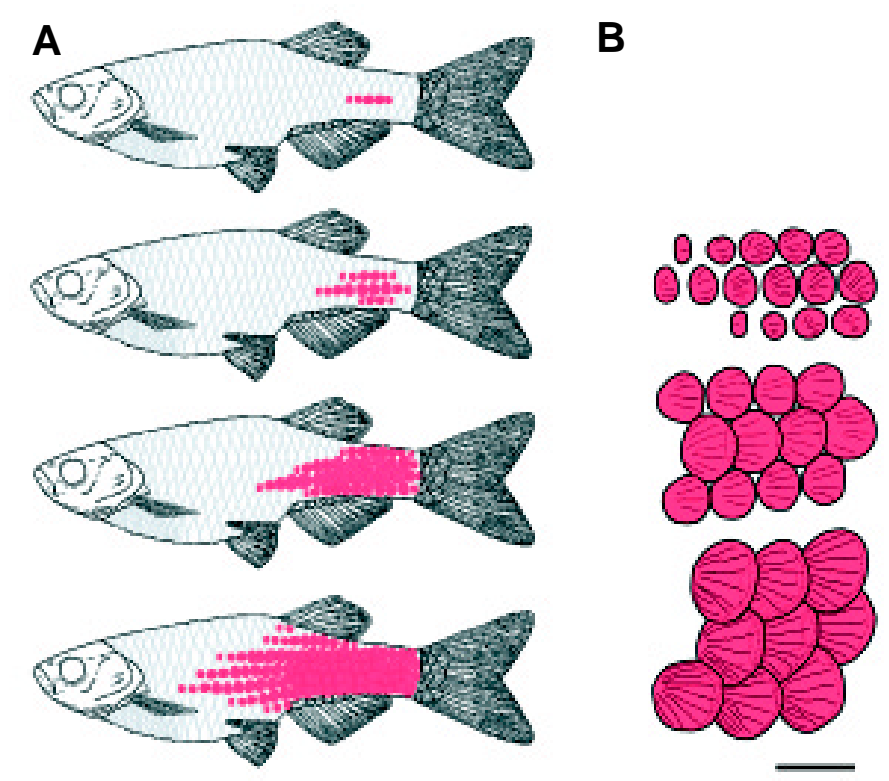

Fig. 4. Development of the squamation pattern in 30 day-old zebrafish. Drawn from alizarin red-stained specimens. Not drawn to scale. From top to bottom: $8.2 \mathrm{~mm}, 8.6 \mathrm{~mm}, 9.2 \mathrm{~mm}$ and $9.5 \mathrm{~mm}$ SL zebrafish. (A) Scales appear late and in well-defined loci of the skin, first in the region of the caudal peduncle, the squamation then spreads anteriorly and laterally. (B) Camera lucida drawings of some scales. From top to bottom: $8.6 \mathrm{~mm}$, $9.2 \mathrm{~mm}$ and $9.5 \mathrm{~mm}$ SL specimens. Note the progressive overlapping of the scales. Bar in B, $500 \mu \mathrm{m}$. 
A
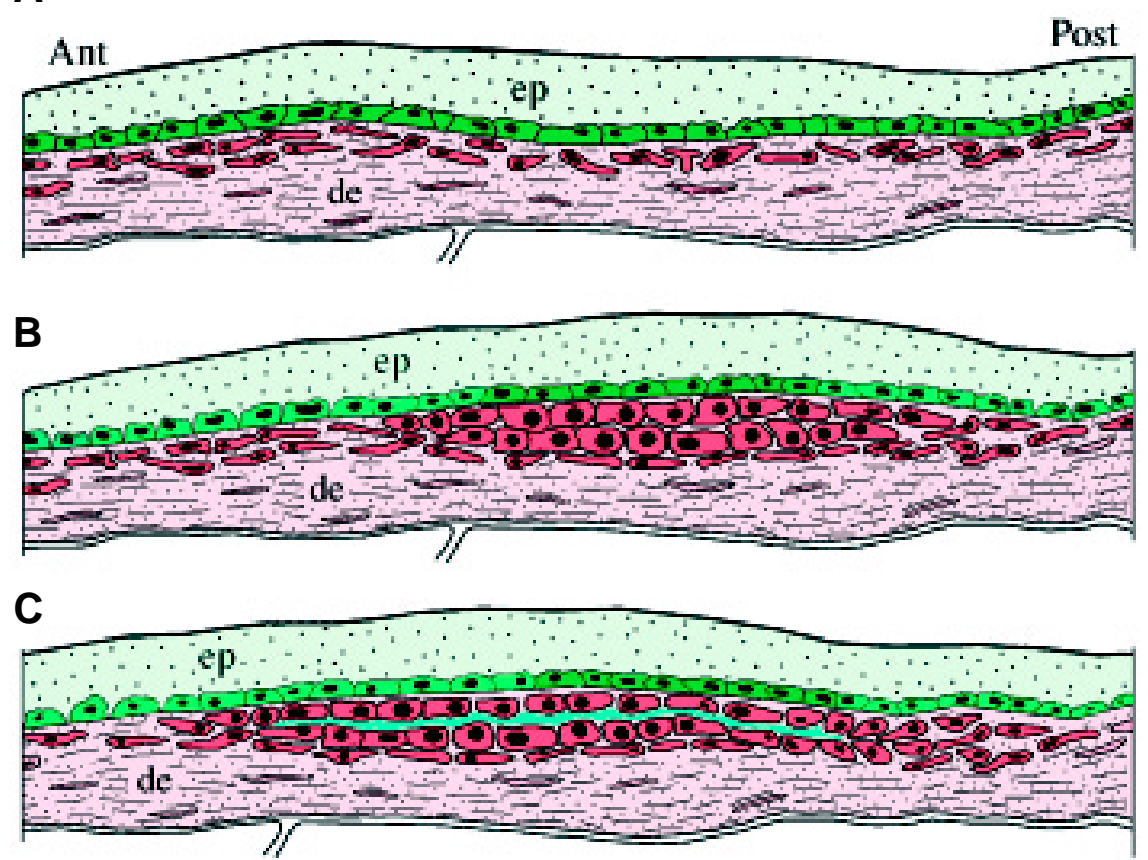

D

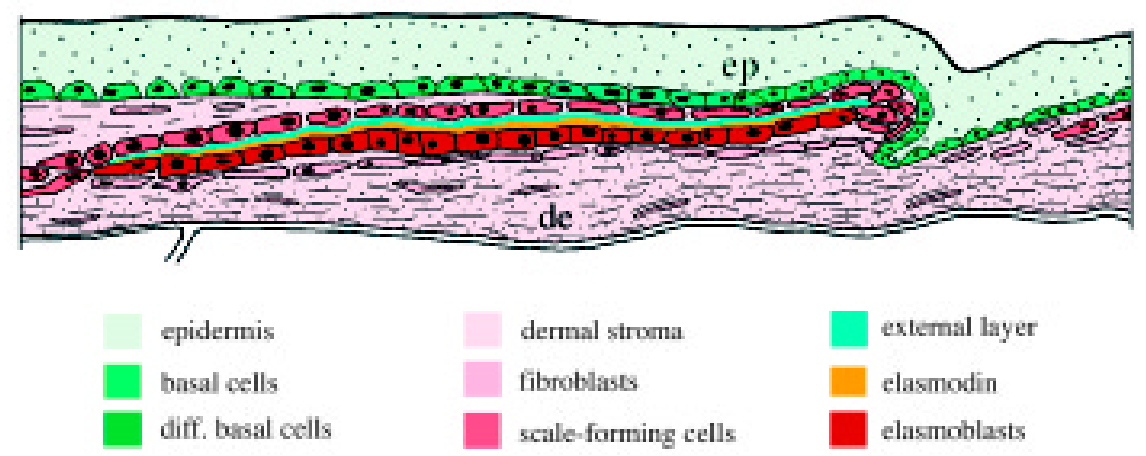

Fig. 5. Interpretative drawings of the various steps of scale development in zebrafish. Drawn from light and TEM micrographs of longitudinal sections of the skin of 30 day-old specimens. (A) Early morphogenesis (scale initiation). Fibroblasts accumulate in the upper region of the dermis facing the differentiated basal layer of the epidermis. (B) Late morphogenesis (scale papilla). The scale papilla differentiates in well-defined region of the dermis. (C) Early differentiation. The first matrix of the external layer is deposited between the two upper layers of the papilla cells. (D) Late differentiation and epidermal folding. The external layer extends, contributing to an enlargement in scale diameter. At the deep surface of the scale the second layer, elasmodin, starts to be deposited due to the activity of scale-forming cells (elasmoblasts) which have entered a second phase of differentiation. The anterior region of the scale slightly sinks into the dermis, whereas its posterior region protrudes into the epidermis, which forms a fold around it.

and their organisation suggests that they can exert traction forces upon the skin (Gemballa and Bartsch, 2002; Gemballa and Vogel, 2002). The vertical collagen bundles that form in the primary dermal stroma long before scale initiation could be related to the anchoring of the myoseptal tendons, and could thus participate in skin patterning. The relation between the organisation of the myoseptal tendons and the skin pattern, and the establishment of the latter during the 25-30 day period preceding scale initiation, obviously deserves to be studied in more detail.
To explain why the squamation pattern is usually initiated at the level of the caudal peduncle, Sire and Arnulf (1991) have proposed the hypothesis that the tension transmitted to the skin during swimming could induce scale development in this region as a means to resist excessive bending. Similarly, Sire et al. (1997b) have suggested that the tension transmitted to the skin delimits precise areas in which the scales are able to develop. These physical constraints acting on a pre-patterned skin suggest that the formation of the first scales in specific, predefined loci, is under the influence of epigenetic factors. Obviously, this does not preclude that a genetic cascade controls the induction of the squamation pattern and subsequent scale development. This molecular control probably involves the same genes that are known to control the induction of epithelial appendages (Crowe et al., 1998; Viallet et al., 1998; Wolpert, 1998; Chuong et al., 2000a; 2000b). To improve our understanding of skin patterning and scale initiation in fish, we need to study the expression pattern of the numerous genes (fgf, bmp, shh, and many others) already known to be involved in skin patterning and epithelial appendage morphogenesis in mouse and chick (Jung et al., 1998; 2004). In the second part of this paper we will focus on the expression pattern of sonic hedgehog, shh, a candidate gene to act in the control of scale morphogenesis.

\section{Scale development}

A review of the different steps leading to the terminal differentiation of the skin prior to scale development is presented in Le Guellec et al. (2004). The development of elasmoid scales, from initiation to terminal differentiation, has been studied in detail at the light and electron microscopical level in a cichlid fish (Sire and Géraudie, 1983) and, more recently, in the zebrafish (Sire et al., 1997b). Other, albeit disparate, data are available for other teleost species, including salmonids (see Sire, 1987). Fibroblasts have invaded the primary dermal stroma, which is mainly composed of a collagenous matrix organised into a plywood-like structure, constituting the future stratum compactum of the dermis. Detailed observations suggest that these fibroblasts do not derive from the dermal endothelium located at the deep surface of the dermis. Indeed, the first fibroblasts observed to penetrate into the collagenous stroma are located along the midline, at the level of the connections with the myoseptal tendons. Possibly, the cells use the collagenous bundles of these tendons to migrate towards the dermis from a deeper location within the body. Some of these fibroblasts are the precursors of the dermal papilla, i.e., the scale-forming cells, but their precise embryonic origin is still unknown. A neural crest origin of these cells has been suggested based on the observation 
that fish tumor pigment cells differentiate and form scales in vitro (Matsumoto et al., 1983). The suggested evolutionary origin of scales from dental elements also supports the neural crest origin of the scale-forming cells. Indeed, during tooth development the mesenchymal cells are known to originate from a population of neural crest cells (Chibon, 1966; Lumsden, 1984). The invasion of the dermal stroma by fibroblasts is concomitant with the differentiation of the whole basal epidermal layer of cells. This correlation suggests either that the fibroblasts penetrating the dermis have informed the epidermal cells, or vice versa, or that these transformations are the result of a general stimulation through long-range signalling molecules.

Shortly after the fibroblasts have penetrated the dermal stroma, some of them accumulate along the basal epidermal surface, adjacent to the basement membrane, and start to differentiate. Five steps can be distinguished (Fig. 5):

1 - early morphogenesis, i.e., the accumulation of fibroblasts along the epidermal-dermal boundary (Fig. 5A);

2- late morphogenesis, characterized by the differentiation of scale papillae immediately below the epidermis and at precise loci among the population of accumulated cells (Fig. 5B);

3- early differentiation, in which the two upper cell layers of the scale papillae differentiate into scale-forming cells and deposit the first-scale matrix of the external layer in between (Fig. 5C);

4- late differentiation, when the scale-forming cells located at the deep surface of the scale matrix differentiate into particular cells, the so-called elasmoblasts, responsible for the deposition of elasmodin, the plywood-like tissue (Fig. 5D; see also Fig. 1);

5- folding, when the epidermis starts to fold around the posterior margin of the scale, a step which also corresponds to the overlap with the neighbouring scales.

During these five steps the anterior region of the scales progressively withdraws from the epidermis surface and sinks in the dermal stroma. The scales become obliquely oriented in the dermis whereby only the posterior region remains in contact with the epidermis (Fig. 5D). In the absence of molecular data, the developmental sequence, together with morphological evidence for the differentiation of the cells in the dermis, as well as in the basal layer of the epidermis, suggests the following dynamical interpretation. Shortly before step 1 , the basal epidermal cells are differentiating on the whole surface suggesting that a general signal (long-range signalling molecules?) has reached these cells, but with no restriction to specific regions. During step 1 (early morphogenesis, Fig. 5A), numerous fibroblasts accumulate in the upper region of the dermis, along the basal surface of the epidermis. This indicates that they have been attracted towards the entire subepidermal region, but that this attraction is not restricted to particular regions. However, some fibroblasts remain in the deep regions of the dermis, suggesting that the attraction could be selective for a particular population of fibroblasts (those located only in the upper region of the dermis?). Unlike the deep fibroblasts, those that have accumulated along the epidermal surface start to differentiate. Step 2 (scale papillae, Fig. $5 \mathrm{~B}$ ) is characterised by the segregation of fibroblasts in particular regions, corresponding to the chessboard pattern on the skin (see above). These two steps are similar to what happens during skin formation in amniotes (Dhouailly, 2004). These subsets of fibroblasts continue their differentiation process and proliferate, as indicated by the numerous mitotic pictures, to form scale papillae. This suggests that new, but strictly local signals (short-range signalling molecules?) have replaced the first, general signal. The fibroblasts facing the other regions of the epidermis arrest their differentiation process and persist in the dermis as standard fibroblasts. The scale papillae enlarge to reach three cell layers, but only the two upper cell populations continue their differentiation into scale-forming cells. The fibroblasts located below arrests their differentiation process, but the cells persist at the deep surface of the papillae and will constitute the so-called scale-pocket lining (Sire, 1989). This suggests that all the cells that constitute the scale papillae, including those of the deep layer, now belong to a specific cell population. Interestingly, when a scale is lost, the scale-pocket lining cells are recruited to regenerate a new scale (Sire and Géraudie, 1984; Sire, 1989). These cells, therefore, seem to function as local stem cells. During the differentiation phase, the basal epidermal cells located at a distance from the surface of the scale papillae no longer show features of anchoring cells (bundles of microfilaments). During step 3 (first matrix deposition, Fig. 5C) the two upper cell layers of the papillae have differentiated into scale-forming cells, responsible for the deposition of the woven-fibred matrix of the external layer. The next steps (deposition of the elasmodin and epidermal folding, Fig. 5D) are characterised by the differentiation of the scale-forming cells located at the deep surface of the scale into elasmoblasts, cells that produce the regular plywood-like collagenous layers. The scale reorients into a slightly oblique position and the epidermal cells located at the extremity of the posterior region appear to be actively involved in protein synthesis; elsewhere, the epidermal cells show an increase in bundles of microfilaments.

The above dynamic interpretation clearly allows for the existence of a genetic cascade that correlates with cell morphology and behaviour in the epidermis and in the mesenchyme.

\section{Molecular data}

To our knowledge only two studies report gene expression during scale development, albeit as a side-observation. In a study on fin regeneration and development in the zebrafish, Monnot et al. (1999) report the epidermal expression of the apolipoprotein $E$ $(a p o E)$ gene. This lipid-binding and lipoprotein receptor-binding protein is known to play an important role in the transport and metabolism of plasma cholesterol and triglycerides. During scale development $a p o E$ transcripts were detected in the basal cell layer of the epidermis, first in the entire surface above the developing scale, but next restricted to the epidermal cells covering the posterior region of the scales. This expression pattern, that correlates with the differentiation of the epidermal basal cell layer, suggests that apoE may play a specific role in scale differentiation and particularly in the regions where epidermal-dermal interactions might occur. This function could be related to lipid uptake and redistribution, probably in relation with the need of a rapid increase of the basement membrane when the epidermis starts to fold around the posterior region of the scale. apoE expression could also be related to the delivery of cholesterol that binds to the signalling molecule sonic hedgehog (shh), which participates in the development of the scale (see following).

The second molecular data concerns the mutation of the rs-3 (reduced scale-3) locus in the medaka, which has been reported 
to lead to an almost complete loss of scales (Kondo et al., 2001). This locus encodes ectodysplasin-A receptor (EDAR), a TNF-like type I transmembrane protein, which is known to be required for the initiation of hair development (Laurikkala et al., 2002). The rs3 mutation, due to the insertion of a transposon in the first intron of $E D A R$, thus provoking an aberrant splicing, shows that this gene is also required for scale initiation in fish. In this mutant, a few scales, larger in size and irregular in shape, are principally located around the dorsal fin and along the lateral line. Remarkably, a similar scale pattern is well-known in carp (Cyprinus carpio) mutants and we can ask the question whether this is the same mutation. Whole-mount in situhybridisation of wild-type medaka reveals that $E D A R$ is expressed in the basal cell layer of the epidermis above the scale papillae and is then restricted to the posterior margin of the growing scales (Kondo et al., 2001). Given that most scales do not form in rs-3 mutants we postulate that $E D A R$ is involved in early scale morphogenesis and that it should be an important actor in the cross talk between the epidermal basal cells and the differentiating scale-forming cells below. The defect in EDAR probably leads to an arrest of the differentiation of the papillae. The presence of some scales in scarce regions suggests a possible genetic redundancy and/or a different genetic pathway. However, further investigations are necessary (1) to reveal how scales develop morphologically in these mutants and (2) to check whether or not $E D A R$ is the earliest marker of scale development. In mice, EDAR expression is first uniformly distributed throughout the embryonic epidermis and later localised to hair placodes. Thus, although fish scales and mammalian hairs are evolutionary unrelated appendages, their morphogenesis may use the same molecular pathway. Clearly, EDAR and ApoE are similar in terms of the spatial and temporal distribution of their transcripts. Next, we will describe a similar pattern for sonic hedgehog (shh) expression during scale development.

\section{sonic hedgehog expression during scale development in the zebrafish (Danio rerio)}

Sonic hedgehog (shh) is known to play important roles in organogenesis (see review, e.g., in Smith, 1994; Perrimon, 1994; Ingham and McMahon, 2001). This vertebrate gene orthologous to the Drosophila segment polarity gene, hedgehog $(h h)$ which encodes a signalling molecule involved in a wide variety of cell processes including the mediation of cell-cell communication. The expression pattern and functional studies of shhin vertebrate model species (mouse, chick and zebrafish) have revealed that this gene is involved in the development of various organs as, e.g., the neural tube, the somites (Johnson et al., 1994; Fan and Tessier-Lavigne, 1994; Fan et al., 1995), limb and fin buds (Krauss et al., 1993; Laufer et al., 1994), skin appendages (Bitgood and McMahon, 1995; Nohno et al., 1995; Iseki et al., 1996), teeth (Bitgood and McMahon, 1995; Iseki et al., 1996; Koyama et al., 1996), lung (Bellusci et al., 1997) and fin rays (Laforest et al., 1998; Quint et al., 2002). Reciprocal epithelialmesenchymal interactions control morphogenesis, differentiation and growth of most organs. They take place through the actions of a wide range of intra- (transcription factors, transmembrane receptors) and extracellular (signalling) molecules, which intervene at different steps of organogenesis. The most exciting results indicate that (1) the same genetic cascades control orga- nogenesis of various organs as, e.g., teeth, limbs, neural tube, skin appendages, lung, etc., and (2) that these genetic pathways are remarkably conserved during evolution (see review in Thesleff et al., 1995a; Thesleff and Sharpe, 1997).

Below, we examine shhexpression during scale development in the zebrafish. Our results show that (1) shh is expressed from late morphogenesis onwards by a small cell population of the basal epidermal layer located above the developing scales, (2) the expression becomes progressively restricted to the posterior region of the scale, and (3) shh is not involved in skin and squamation patterning. Such a pattern of expression suggests that the basal epidermal cells use the signalling molecule shh to regulate scale-forming cells in the regions that are in close relationship with the epidermal cover.

\section{Results}

Spatio-temporal expression of shh

The first signals are observed on both flanks, in the caudal peduncle of 8.4-8.6 mm SL specimens. Several spots of various shapes are disposed, at regular intervals, in three longitudinal rows, the middle row possessing more spots than the adjacent

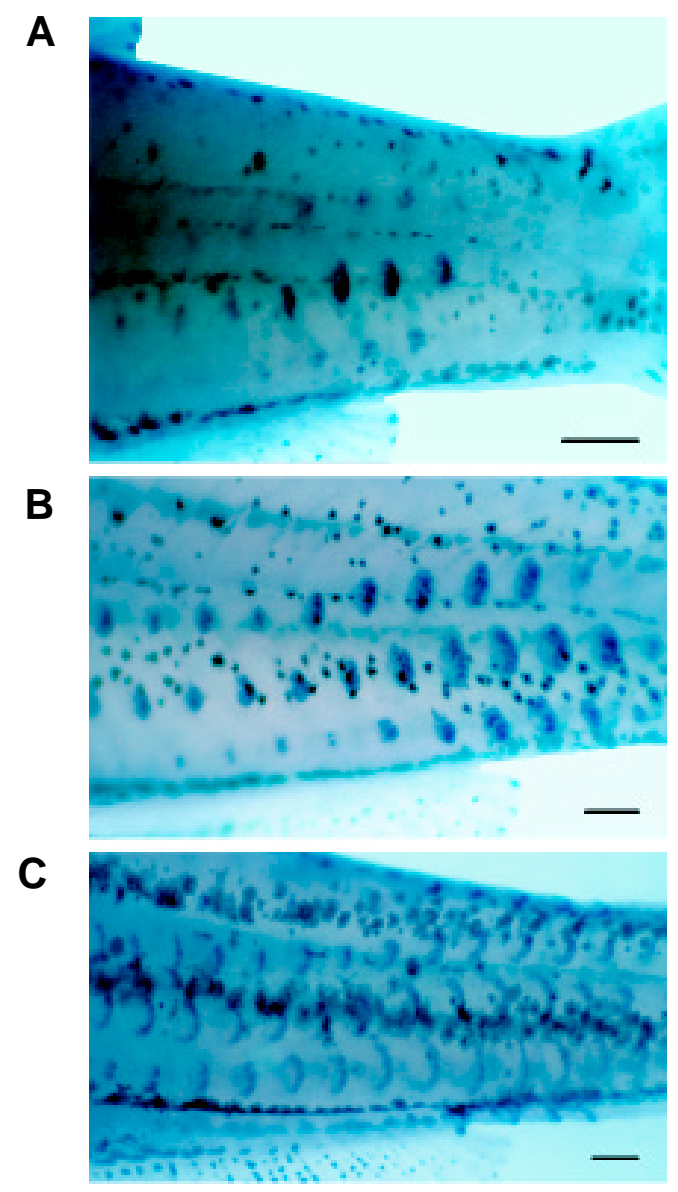

Fig. 6. shh expression patterns in the left flank of three $\mathbf{3 0}$ day-old zebrafish specimens at a different stage of squamation development. (A) $8.5 \mathrm{~mm} \mathrm{SL;} \mathrm{(B)} 9.0 \mathrm{~mm} \mathrm{SL;} \mathrm{(C)} 9.5 \mathrm{~mm} \mathrm{SL}$. Compare with the squamation pattern from alizarin red-stained specimens in Fig. 4A. shh is expressed in several cell populations, either rounded, ovoid or crescentshaped. Bar, $250 \mu \mathrm{m}$. 
rows (Fig. 6A). The spots are small and rounded, and of weak intensity, in the anterior part of a row, and large and ovoid, and of stronger intensity, in the middle and posterior part of a row. In 8.7$9.0 \mathrm{~mm}$ SL specimens, the three rows contain new spots, prolonging the rows both anteriorly and posteriorly, whereas the first to be formed are now becoming larger, ovoid for those located at the row extremities, and crescent-shaped in the central region of the rows (Fig. 6B). In $9.5 \mathrm{~mm}$ SL zebrafish, new rows have appeared ventrally and dorsally to the previous rows. The latter are completed anteriorly and posteriorly. The body is nearly entirely covered now by regularly disposed, narrow crescent-shaped labelled areas, with the convex margin directed backwards (Fig. $6 \mathrm{C})$. In 12 week-old zebrafish, the crescent-shaped signals are narrow and of weak intensity, but the pattern is still observable over the entire body surface (data not shown).

The pattern of shh expression correlates to the pattern of squamation described in alizarin red-stained specimens (compare Fig. 6 with Fig. 4A). Each hybridisation signal area corresponds to the locus of a developing scale. Yet, the cell populations expressing shh cover a smaller surface compared to that of the developing scale, which itself remains roughly rounded during growth (Fig. 4B). At a given position, the shh-expressing cells are first located in a small rounded population, then into an ovoid cluster, and finally in a crescent-shape zone. The slide-mounted dissected skin of hybridised specimens shows that the successive expression patterns are clearly related to the different stages of scale development: small, rounded spots correspond to the central region of early developing scales; large, ovoid signals are located above the posterior region of developing scales, and large crescent-shaped cell clusters are restricted to the posterior margin of well-formed scales (Fig. 7 A-C, respectively). The comparison of alizarin red-stained and whole mount in situ hybridised specimens of the same size/age reveals that shhtranscripts are never detected in skin regions devoid of scales.

The number of shh-expressing cells has been evaluated at each step of scale development: 40-50 (10 high/4-5 wide) at late morphogenesis (round-ovoid spots); $60-80$ cells (15-20 high/4-5 wide) during early scale differentiation (ovoid clusters); 60-100 cells (20-25 high/3-4 wide) at late differentiation (ovoid/crescentshape areas); $50-90$ cells (25-30 high/2-3 wide) when the scale surface extends (crescent-shape zones); and 40-80 cells (40 high/1-2 wide) around the posterior margin of the scales in juvenile zebrafish. Longitudinal sections show that the basal epidermal cells, which do not directly face developing scales never express shh. Transcripts of shhare found from late morphogenesis to epidermal folding stage in cells of the basal epidermal layer located above the scale surface (Fig. 8). On a section, no signal is observed in the mesenchyme, neither before nor during scale development. Yet, only a few epidermal cells express $s h h$. 4-5 cells above the scale papilla at late morphogenesis, 3-4 cells at early differentiation, 2-3 cells at late differentiation, and only 1 2 cells when the epidermis folds around the posterior margin of the scale (Fig. 8 B-E, respectively). No transcripts are detected in the epidermis before the formation of scale papillae, i.e., during the period when fibroblasts invade the primary dermal stroma and accumulate along the basal epidermal cell surface (Fig. 8A).

The spatial expression pattern of shhis similar if one considers scales in the same developmental stage either within an individual, or in different, but similar-sized/aged specimens.

\section{Ultrastructural observations (TEM)}

Below, we use TEM observations to document specific stages of scale development in which the morphological features of the epithelial and mesenchymal cells can be correlated to shhexpression in the epidermis (Fig. 9). More information on zebrafish scale development at an ultrastructural level is given in Sire et al. (1997b).

During the period of skin development preceding the invasion of the dermal stroma by fibroblasts, the cytoplasm of the basal epithelial cells is characterised by the presence of numerous bundles of microfilaments. These microfilaments are essentially located in the region of the cytoplasm facing the primary dermal stroma. Their main function is to anchor the epidermis to the basement membrane (see Le Guellec et al., 2004). Concomitant to the invasion of the dermal stroma by fibroblasts, the basal epithelial cells start to differentiate throughout the entire layer. The bundles of microfilaments progressively disappear and are replaced by numerous organelles. During early scale morphogenesis, when fibroblasts accumulate in the upper region of the dermal stroma close to the epidermal surface, the morphological features of the basal epithelial cells are unchanged with a large number of organelles, indicative of active protein synthesis (Fig. 9 A,B). During the stage of scale-papillae the basal epithelial cells do not change much (Fig. 9C). During early scale differentiation,

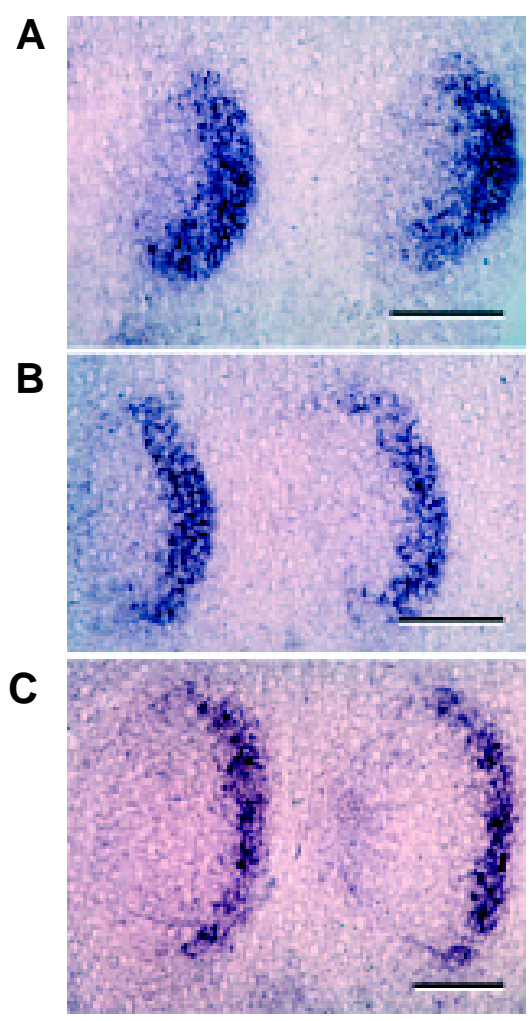

Fig. 7. Detail of shh expression pattern in pieces of skin removed from the body. (A) shh transcripts are located in a round-ovoid cell population above the developing scales. (B) The cell population expressing shh is located above the posterior region of the scales only. (C) The shh signal is restricted to cells at the posterior scale margin, where they are distributed over a crescent-shaped area. Bar, $100 \mu \mathrm{m}$. 

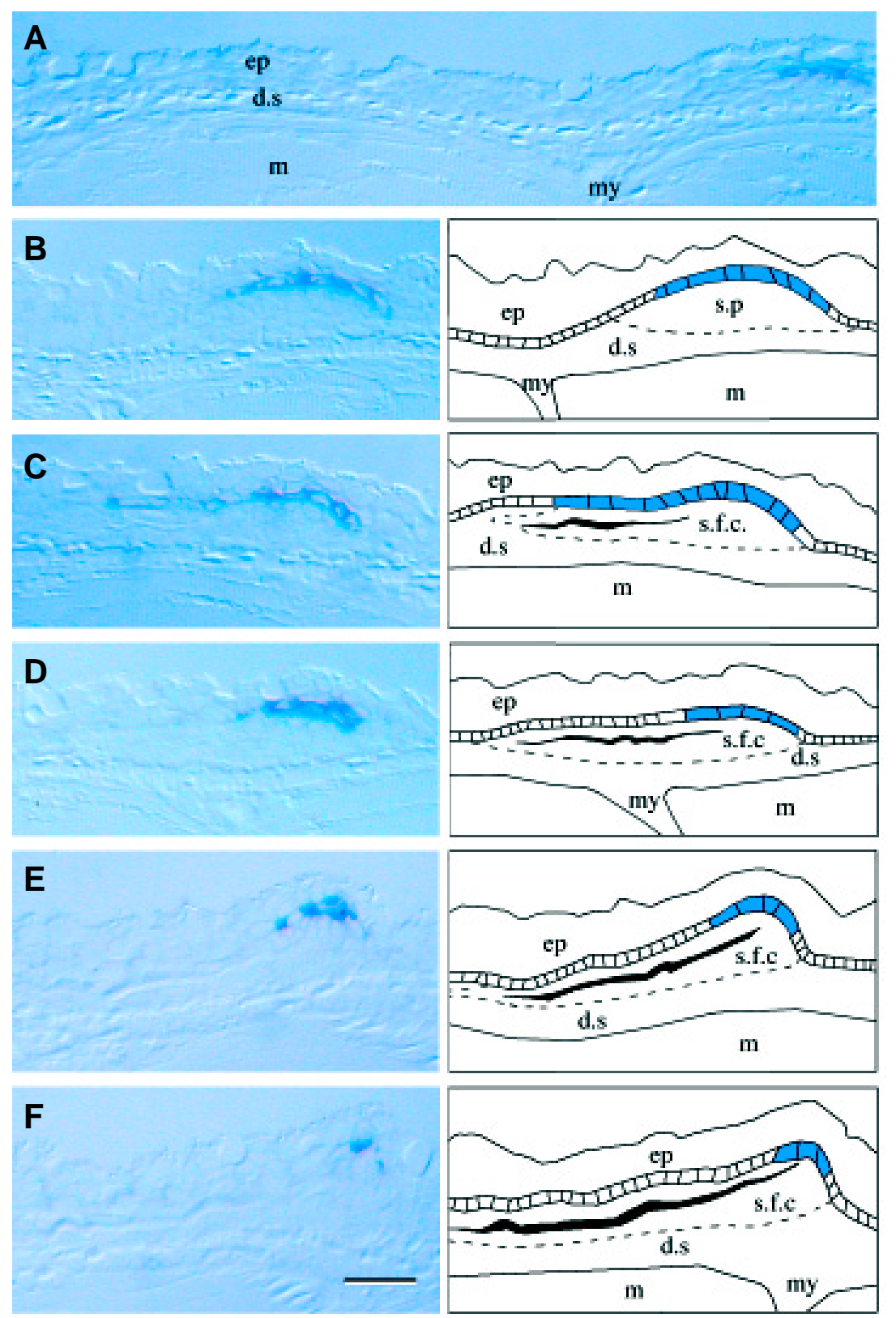

Fig. 8. Longitudinal sections ( $2 \mu \mathrm{m}$ thick) of epon-embedded, whole mount shh in situ hybridised 8.8-9.2 $\mathbf{~ m m ~ S L ~ z e b r a f i s h . ~ A n t e r i o r ~ t o ~ t h e ~ l e f t . ~ ( A ) ~ S c a l e ~ i n i t i a t i o n . ~}$ On the left, no shh transcripts are detected in the skin shortly before scale papilla formation, where fibroblasts are accumulated along the deep surface of the epidermis. On the right, a scale papilla has been formed and shh expression is detected in the basal epidermal cells. (B-F) Interpretative drawings of the presented sections. The cells of the basal epidermal layer that express shh are in blue and the scale matrix is in black. The dotted line represents the limit between the dermal stroma and the scale-forming cell population. (B) Formation of a scale papilla. The cells of the epidermal basal layer located above the well-formed scale papilla express shh. (C) Early differentiation. The epidermal cells expressing shh are located above the developing scale, the matrix of which starts to be deposited. (D) Late differentiation. The shh signal is now only detected in cells which cover the posterior region of the forming scale. (E,F) Epidermal folding. shh expression is progressively restricted to a few epidermal cells located in the region that folds around the posterior scale margin. Bar, $25 \mu \mathrm{m}$. Abbreviations: d.s, dermal stroma; ep, epidermis; m, muscle cells; my, myoseptum; s.f.c, scale-forming cells; s.p, scale papilla. the cytoplasm of the mesenchymal cells is enriched in RER cisternae, Golgi systems, and secretory vesicles, features indicative of scale matrix synthesis, and the epidermal cells located immediately above the scale-forming cells maintain the features reported above (Fig. 9D). During late scale differentiation and epidermal folding stage, when the scale enlarges in surface and becomes oriented slightly obliquely within the dermis, the number of epidermal cells showing typical features of protein synthesis progressively reduces as these cells become restricted to the posterior scale surface (Fig. 9E). They face a small number of scale-forming cells, which produce the scale matrix at the posterior margin of the scale, resulting in a rapid extension in scale diameter. Elsewhere, in the epidermal basal layer bundles of microfilaments reappear and progressively enrich the cytoplasm (Fig. 9F).

\section{Discussion}

Using a combination of in situ hybridisation, light and transmission electron microscopy, we have been capable to link shh expression to differences in cell morphology during late scale morphogenesis and differentiation. We show that, in zebrafish, (1) shh transcripts are not detected in the skin until dermal scale papillae are differentiating, (2) shh is only expressed in basal epithelial cells, (3) the pattern of expression of $s h$ is progressively restricted to the posterior margin of developing scales, and (4) morphological features of the basal epithelial cells suggest active synthesis of proteins directed to the secretory pathway.

\section{shh is expressed only in the epidermis}

In the posterior region of the scale, shh expression is sustained during growth at a level detectable by whole mount ISH, even in $25 \mathrm{~mm}$ SL zebrafish. Although shhexpression pattern has been reported in various developing organs, such a persistent pattern of expression has only been reported for the fin rays (Laforest et al., 1998), and is probably related to the continuous growth of these elements. This suggests that shh may be involved in the growth of these elements, but only at their posterior extremity, which has an intimate relationship with the epidermal cover. It is more relevant to compare features of scale development to those of fin rays and teeth (evolutionary closely related) and, to a lesser degree, of other skin appendages (sensu Maderson, 1972) like hairs and feathers. In all types of skin appendages, shhgene has been reported to be only expressed in the basal epithelial cell layer, similar to what has been described here for scale development, but there are, nevertheless, some temporal differences. During hair and feather development, shhtranscripts are detected in the epidermis at the placode stage, which either slightly preceds or is concomitant to dermal condensation (Bitgood and 
Fig. 9. TEM micrographs of selected regions of the skin at various stages of scale development (compare with Figs. 5 and 8). (A) Early morphogenesis (scale initiation) stage. Fibroblasts have accumulated along the deep surface of the epidermis and possess a large nucleus. The epidermal basal layer cells are differentiating. (B) Detail of the epidermal basal layer cells (arrow in A) facing the accumulated fibroblasts. Some cisternae of the rough endoplasmic reticulum and a well-developed Golgi system (arrow) surrounded by numerous small vesicles are visible. Some bundles of microfilaments are also present along the basement membrane. (C) Late morphogenesis (scale papillae) stage. Detail of epidermal basal cells located above the centre of a scale papilla. The cytoplasm is rich in organelles and numerous small vesicles are visible. (D) Early differentiation (deposit of the first scale matrix) stage. This epidermal cell is located above the posterior region of a developing scale. Note the large amount of organelles that fills the cytoplasm. (E) Late differentiation and epidermal folding stage. This epidermal basal layer cell is located above the posterior margin of a well-developed scale. (F) Same stage. Epidermal basal cells are located at the scale surface, but at a distance from the posterior region of the scale. Its cytoplasm is enriched with bundles of microfilaments. Bars: A, $2 \mu \mathrm{m} ; B, E, F, 250 \mathrm{~nm} ; C, D$, $500 \mathrm{~nm}$. ep, epidermis; me, mesenchyme.
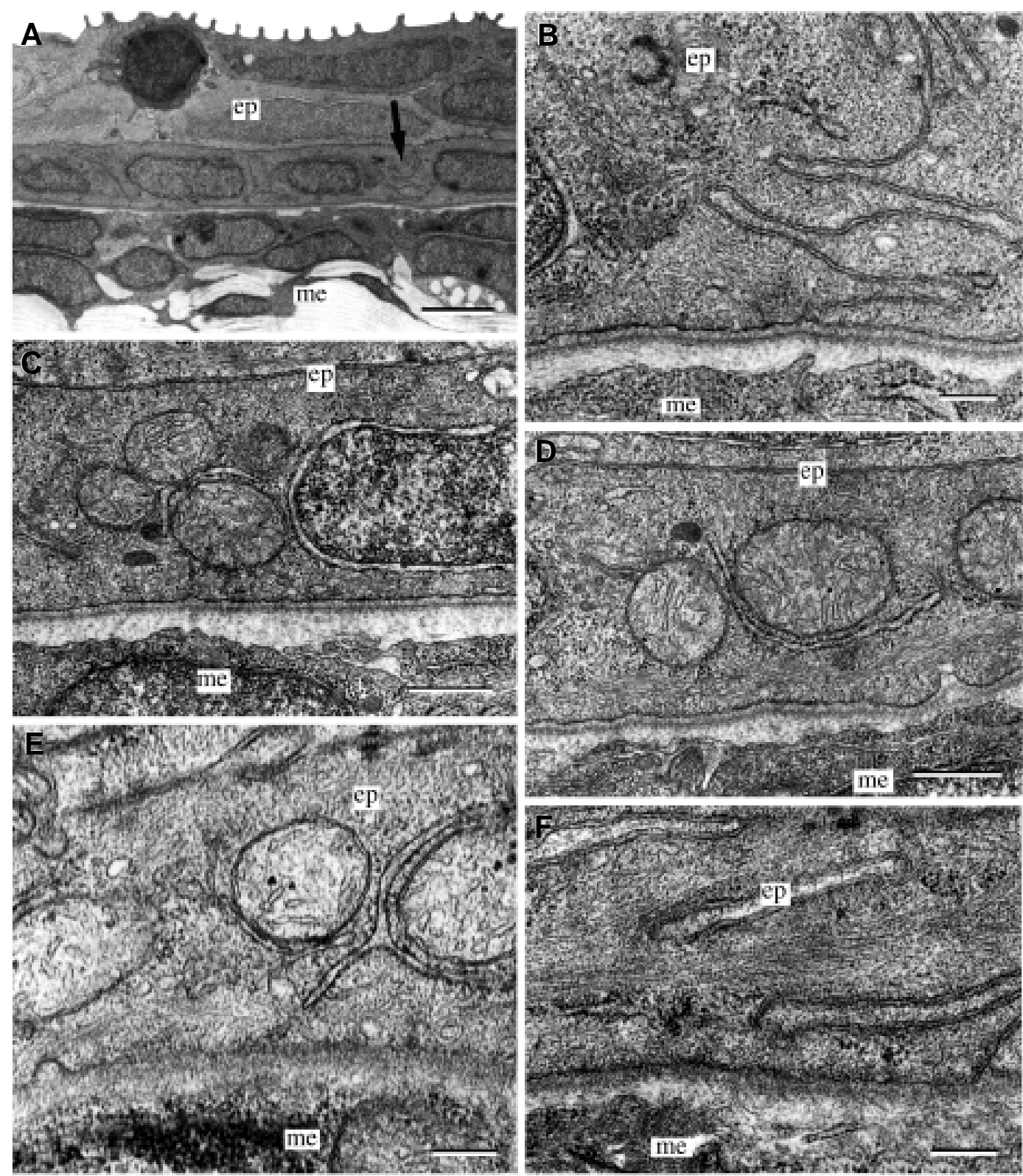

McMahon, 1995; Nohno et al., 1995; Iseki et al., 1996). Typical placodes, i.e., thickenings of the basal epithelial layer at specific loci, have not been identified morphologically in fish epidermis, not even in the period shortly preceding the differentiation of the scale papilla, when shhexpression is first detected (late morphogenesis). In mouse tooth development, shhis early expressed in the oral epithelium, either just before or during the initiation of odontogenesis at gestational day 11, when the dental lamina differentiates (Bitgood and McMahon, 1995; Kronmiller et al., 1995; Koyama et al., 1996; Dassule and McMahon, 1998). In addition, shh expression is detected in a specific region of the enamel organ, the so-called enamel knot that controls tooth morphology (Thesleff et al., 1995b; Thesleff and Sharpe, 1997). The tooth bud stage is temporally and spatially equivalent to the scale papilla stage, the first stage at which shhis detected during scale development.
During zebrafish fin ray development, shh expression is detected in a subset of cells in the basal epithelial layer, in the distal part of the developing bony rays and in the close proximity of the newly differentiated bone-forming cells (Laforest et al., 1998). In addition, the shh transmembrane receptor patched1 (ptc1) and the bone morphogenetic factor bmp2b, a secondary signal activated following shh signalling, are both expressed in the boneforming cells adjacent to the epithelial cells expressing shh. Moreover, it was shown that ectopic shh expression in the fin tissue induces ectopic bone formation possibly through the recruitment of new bone-forming cells (Quint et al., 2002). Likewise, during scale development preliminary observations indicate that ptc 1 and $b m p 2 b$ are expressed in scale-forming cells facing the epidermal cells expressing shh (Sire, unpublished data). shh is thus expressed in a similar pattern in the scales and fin rays, in a subset of cells of the basal epithelial layer adjacent to scale- or 
bone-matrix producing cells. This strongly supports the hypothesis of conservation of a common function of the shh signalling pathway in these two evolutionary closely related systems.

In brief, Shh does not seem to be essential for patterning the squamation and for scale initiation (early morphogenesis), but it is involved in the differentiation of the mesenchymal cells located immediately below, as already described for other epithelial appendages (Ingham, 1998; Chuong, 1998; Chuong etal., 2000a, 2000b).

shh is expressed in particular epidermal cells during scale deve/opment

Not only is shhexpression restricted to specific regions of the basal epidermal layer, opposite the scale-forming cells, but cells expressing shh are precisely those located the closest to the differentiated scale-forming cells. As the scales progressively become re-oriented within the dermis, only their posterior region remains in contact with the epidermis. This correlates to the progressive restriction of the shh signal to this region. This particular location also suggests that the targets of the shortrange signalling molecule shh are the scale-forming cells, responsible for the extension of the posterior margin.

These findings are in accordance with the possible function of shh. As known for other segment polarity genes (e.g., hh ) in Drosophila, shh in vertebrates is thought to be involved in the control of cellular interactions involved in positional specification along the antero-posterior axis. Indeed, all organs in which shh expression has been detected are known to be polarised. The restriction of shhexpression to the margin of the posterior region of the scales suggests that this gene (and the shh signalling pathway) is involved in the control of the epidermal-dermal interactions, responsible for the harmonious growth of this area with respect to the growth of the epidermal covering. At the same time, localised shh expression is in agreement with a possible function in defining the antero-posterior axis of the scale.

\section{The advantages and limits of TEM data}

The precise developmental sequence leading to scale papilla formation has been described based on TEM observations (Sire et al., 1997b; Quilhac and Sire, 1999), and has been briefly recapitulated in paragraph "scale development". In the present study, the superimposition of ISH pictures and conventional light and TEM has allowed us to compare the morphology of the epidermal basal layer cells in regions were they are either or not expressing shh. In all the differentiated epidermal basal layer cells in which shhtranscripts are detected, the cytoplasm is characterized by features such as numerous mitochondria, ribosomes and small vesicles, some of them merging with the plasmalemma facing the dermal stroma. These vesicles are involved in the transport of small-sized molecules, some of them likely being shh molecules. Likewise, the epidermal cells which no longer express shh do not present these features and are characterized by numerous bundles of microfilaments in the region of the cytoplasm facing the dermis. By contrast, when shh is not detected, during early scale morphogenesis (i.e., when fibroblasts accumulate in the dermal stroma and further accumulate close to the epidermal surface), the epidermal basal layer cells show a similar morphological aspect as cells expressing shh. These morphological features suggest, therefore, that these epidermal cells are producing other secreted molecules, probably involved in the interaction with the mesenchymal cells, which are subsequently accumulating. Likely candidates which could act as signalling molecules in this step of the genetic cascade belong to the FGF and BMP family.

In all scale-forming cells, the cytoplasmic content is characterized by a large amount of RER cisternae, Golgi systems and numerous, large and small secretory vesicles. These cells are mainly producing type I collagen (see Le Guellec et al., 2004) and some other accompanying proteins. They probably also produce signalling molecules (e.g., BMPs), which enter in the cross talk with the epidermal basal cells.

TEM thus allows a detailed interpretation of the relationship between (1) the expression of a gene coding for a signalling molecule, (2) the precise differential status of the cells which produce this protein (undifferentiated, differentiating or differentiated, secreting matrix components or producing signalling molecules), and (3) the precise status of the cells, which are suspected to be the targets of the signal.

\section{Conclusion}

The pattern of shh expression during scale development and growth in the zebrafish suggests that the epidermal basal layer cells located above the posterior region use the shh signalling molecule to control scale growth. The location and time of expression are in order to obtain an harmonious growth of the posterior region of the scale concomitant with the growth of the epidermal covering. To fulfil this function these epidermal cells use the shh pathway. This finding is also supported by preliminary observations showing that $p t c 1$ and bmp2are expressed in scale-forming cells facing the epidermal cells expressing shh. This supposed function of shh as a short range (i.e. cell-cell interactions) signalling molecule is in accordance with the signalling pathways known for shh in other developing epithelial appendages.

\section{Materials and Methods}

\section{Animals}

Wild-type zebrafish were laboratory-reared under conditions described elsewhere (Sire et al., 1997a, 1997b). We used $30 \mathrm{dpf}$ fish (between 8.0 and $9.5 \mathrm{~mm} \mathrm{SL}$ ), the appropriate stage to study scale development (Sire et al., 1997b), and some older (12 week-old, $25 \mathrm{~mm}$ standard length- SL) specimens to study well-developed scales. The fish were euthanized with an overdose of MS222 and distributed into three sets for immediate processing either for alizarin red staining, whole mount in situhybridisation, or conventional microscopy.

\section{Alizarin red staining}

The fish were fixed in $4 \%$ paraformaldehyde for $24 \mathrm{~h}$ to $48 \mathrm{~h}$, then Alizarin red stained and cleared following a procedure described elsewhere (Sire et al., 1997a).

\section{Whole-mount in situ hybridisation}

The phagemide bluescript with the cDNA was a gift by Drs V. Korzh and $T$. Jessel. The anti-sense shhprobe was synthesized and digoxygenin labelled as described in the zebrafish book (Westerfield et al., 1995). shh cDNA (1600 bp) was linearized with $B g / l l$ and the probe synthesized with T7 RNA polymerase. The hybridisation procedure was performed as described elsewhere (Laforest et al., 1998). Small pieces of labelled skin were delicately removed from the flank of some fish for direct observation using a stereomicroscope. Whole mount hybridised fish were dehydrated 
in a graded series of ethanol and embedded in epon 812. Two to five $\mu \mathrm{m}$ thick longitudinal, serial sections were obtained using a diamond knife and observed, unstained, using a stereomicroscope equipped with a Nomarski device.

\section{Conventional light and transmission electron microscopy}

Fixation procedure of the zebrafish and their embedding in epon are described elsewhere (Sire et al., 1997a). One $\mu \mathrm{m}$-thick sections were observed after toluidine blue staining. Thin sections were contrasted with uranyl acetate and lead citrate, then observed in a 201 Philips EM operating at $80 \mathrm{~V}$.

\section{Acknowledgements}

We are grateful to Professor Ann Huysseune (Ghent University, Belgium) and Professor Danielle Dhouailly (Université de Grenoble) for their suggestions and English improvement. The authors thank Miss F. Allizard and Ms. L. Laforest for technical assistance. TEM work was carried out at the "Service de Microscopie Electronique de I'IFR de Biologie Intégrative - CNRS-Univ. Paris 6".

\section{References}

AGASSIZ, J.L.R. (1844) Recherches sur les Poissons fossiles, 1, XLIX, 188 p., Neuchatel.

BELLUSCI, S., FURUTA, Y., RUSH, M.G., HENDERSON, R., WINNIER, G. and HOGAN, B.L. (1997) Involvement of Sonic hedgehog (Shh) in mouse embryonic lung growth and morphogenesis. Development, 124: 53-63.

BITGOOD, M.J. and MCMAHON, A.P. (1995) Hedgehog and Bmp genes are coexpressed in many diverse sites of cell-cell interaction in the mouse embryo. Dev. Biol., 172: 126-138.

CHIBON, P. (1966) Analyse expérimentale de la régionalisation et des capacités morphogénétiques de la crête neurale chez l'amphibien urodèle Pleurodeles wat//Michah. Mém. Soc. Zool. Fr., 36: 1-107

CHIBON, P. (1967) Marquage nucléaire par la thymidine tritiée des dérivés de la crête neurale chez l'amphibien urodèle Pleurodeles wat//Michah. J. Embryol. Exp. Morphol., 18: 343-358.

CHUONG, C.M. (1998) Morphogenesis of epithelial appendages: variations on top of a common theme and implications in regeneration. $/ n$. Molecular basis of epithelial appendage morphogenesis. pp. 3-14, R.G. Landes, Austin, TX.

CHUONG, C.M., CHODANKAR, R., WIDELITZ, R.B. and JIANG, T.X. (2000a) Evodevo of feather and scales: building complex epithelial appendages. Curr. Opin. Gen. Dev., 10: 449-456.

CHUONG, C.M., PATEL, N., LIN, J., JUNG, H.S. and WIDELITZ, R.B. (2000b) Sonic hedgehog signaling pathway in vertebrate epithelial appendage morphogenesis: perspectives in development and evolution. Cell Mol. Life Sci., 57: 1672-1681.

COOPER, J.A. (1971) Scale development as related to growth of juvenile black crappie, Pomoxis nigromaculatus Lesueur. Trans. Amer. Fish. Soc., 100: 570572.

CROWE, R., HENRIQUE, D., ISH-HOROWICZ, D. and NISWANDER L. (1998) A new role for Notch and Delta in cell fate decisions: patterning the feather array. Development, 125: 767-775.

DASSULE, H.R. and MCMAHON, A.P. (1998) Analysis of epithelial-mesenchymal interactions in the initial morphogenesis of the mammalian tooth. Dev. Biol., 202: 215-227.

DELGADO, S. (2002) L'amélogénine, protéine majeure de l'émail dentaire. Origine, analyses évolutive et phylogénétique chez les amniotes et recherche de son expression lors de la formation des dents de Chalcides viridanus (Squamate, Scincidé). Thèse de Doctorat, Université Paris 7, $280 \mathrm{p}$.

DELGADO, S., CASANE, D., BONNAUD, L., LAURIN, M., SIRE, J.-Y. and GIRONDOT, M. (2001) Molecular evidence for Precambrian origin of amelogenin, the major protein of Vertebrate enamel. Mol. Biol. Evol., 18: 2146-2153.

DHOUAILLY, D., OLIVERA-MARTINEZ, I., FLINIAUX, I., MISSIER, S., VIALLET, J.P. and THÉLU, J. (2004) Skin field formation: morphogenetic events. Int. J. Dev. Biol. 48: 85-92.
ECHELARD, Y., EPSTEIN, D.J., ST-JACQUES, B., SHEN, L., MOHLER, J., MCMAHON, J.A. and MCMAHON, A.P. (1993) Sonic hedgehog, a member of a family of putative signaling molecules, is implicated in the regulation of CNS polarity. Cell, 75: 1417-1430.

FAN, C.M. and TESSIER-LAVIGNE, M.T. (1994) Patterning of mammalian somites by surface ectoderm and notochord: Evidence for sclerotome induction in a hedgehog homolog. Cell, 79: 1175-1186.

FAN,C.M., PORTER, J.A., CHIANG, C., CHANG, D.T., BEACHY, P.A. and TESSIERLAVIGNE, M. (1995) Long range sclerotome induction by Sonic hedgehog: direct role of the amino-terminal cleavage product and modulation by the cyclic AMP signalling pathway. Cell, 81: 457-465.

FRANCILLON-VIEILLOT, H., BUFFRENIL, V. DE, CASTANET, J., GERAUDIE, J. MEUNIER, F.J., SIRE, J.-Y., ZYLBERBERG, L. and RICQLES, A. DE (1990) Microstructure and mineralisation of vertebrate skeletal tissues. In Skeletal Biomineralisation: Patterns, Processes and Evolutionary Trends (ed. J.G. Carter). Short Course in Geology, Vol. 5, Pt II, 175-234.

GEMBALLA, S. and BARTSCH, P. (2002) Architecture of the integument in lower teleostomes: Functional morphology and evolutionary implications. J. Morphol., 253: 290-309.

GEMBALLA, S. and VOGEL F. (2002) Spatial arrangement of white muscle fibers and myoseptal tendons in fishes. Comp. Biochem. Physiol., Part A, 133: 10131037.

HEROLD, R., ROSENBLOOM, J. and GRANOVSKY, M. (1989) Phylogenetic distribution of enamel proteins: Immunohistochemical localization with monoclonal antibodies indicates the evolutionary appearance of enamelins prior to amelogenins. Calcif. Tissue Int., 45: 88-94.

HUYSSEUNE, A. and SIRE, J.-Y. (1998) Evolution of patterns and processes in teeth and tooth-related tissues in non-mammalian vertebrates. Eur. J. OralSci., 106 (suppl. 1): 437-481.

INGHAM, P.W. (1998) Transducing hedgehog: the story so far. EMBO J., 17: 3505 3511.

INGHAM, P.W. and MCMAHON, A.P. (2001) Hedgehog signalling in animal development: paradigms and principles. Genes Dev. 15: 3059-3087.

ISEKI, S., ARAGA, A., OHUCHI, H., NOHNO, T., YOSHIOKA, H., HAYASHI, F. and NOJI, S. (1996) Sonic hedgehog is expressed in epithelial cells during development of whisker, hair and tooth. Biochem. Biophys. Res. Commun., 218: 688693.

ISHIYAMA, M., MIKAMI, H., SHIMOKAWA, H. and OIDA, S. (1998) Amelogenin protein in tooth germs in the snake Elaphe quadrivirgata. Immunohistochemistry, cloning and cDNA sequence. Arch. Histol. Cytol., 61: 467-474.

JOHNSON, R.L., LAUFER, E., RIDDLE, R.D. and TABIN, C. (1994) Ectopic expression of sonic hedgehog alters dorsal-ventral patterning of somites. Cell, 79: 1165-1173.

JUNG, H.-S., FRANCCIS-WEST, P.H., WIDELITZ, R.B., JIANG, T.-X., TINGBERRETH, S., TICKLE, C., WOLPERT, L., and CHUONG, C.M. (1998) Local inhibitory action of BMPs and their relationships with activators in feather formation: Implications for periodic patterning. Dev. Biol., 196: 11-23.

JUNG, H.-S., AKITA, K. and KIM, J.-Y. (2004). Spacing patterns on tongue surfacegustatory papilla. Int. J.Dev. Biol. 48: 157-161.

KONDO, S., KUWAHARA Y., KONDO, M., NARUSE, K., MITANI, H., WAKAMATSU, Y., OZATO, K., ASAKAWA, S., SHIMIZU, N. and SHIMA, A. (2001) The medaka rs-3 locus required for scale development encodes ectodysplasin-A receptor. Curr. Biol., 11: 1202-1206.

KOYAMA, E., YAMAAI, T., ISEKI, S., OHUCHI, H., NOHNO, T., YOSHIOKA, H., HAYASHI, Y., LEATHERMAN, J.L., GOLDEN, E.B., NOJI, S. and PACIFICI, M. (1996) Polarizing activity, sonichedgehog, and tooth development in embryonic and postnatal mouse. Dev. Dyn., 206: 59-72.

KRAUSS, S., CONCORDET, J.P. and INGHAM, P.W. (1993) A functionally conserved homolog of the Drosophila segment polarity gene $h h$ is expressed in tissues with polarizing activity in zebrafish embryos. Cell, 75: 1431-1444.

KRONMILLER, J.E., NGUYEN, T., BERNDT, W. and WICKSON, A. (1995) Spatial and temporal distribution of sonic hedgehog mRNA in the embryonic mouse mandible by reverse transcription/polymerase chain reaction and in situhybridization analysis. Arch. Oral Biol., 40: 831-838. 
LAFOREST, L., BROWN, C.W., POLEO, G., GÉRAUDIE, J., TADA, M., EKKER, M., and AKIMENKO M.-A. (1998) Involvement of the sonic hedgehog, patched 1 and $b m p 2$ genes in patterning of the zebrafish dermal fin rays. Development, 125: 4175-4184.

LAUFER, E., NELSON, C.E., JOHNSON, R.L., MORGAN, B.A. and TABIN, C. (1994) Sonic hedgehogand Fgf-4act through a signaling cascade and feedback loop to integrate growth and patterning of the developing limb bud. Cell, 79: 9931003.

LAURIKKALA, J., PISPA, J., JUNG, H.-S., NIEMINEN, P., MIKKOLA, M., WANG, X., SAARIALHO-KERE, U., GALCERAN, J., GROSSCHEDL, R. and THESLEFF, I. (2002) Regulation of hair follicle development by the TNF signal ectodysplasin and its receptor Edar. Development, 129: 2541-2553.

LEGUELLEC, D., MORVAN-DUBOIS, G. and SIRE, J.-Y. (2004). Skin development in bony fish with particular emphasis on collagen deposition in the dermis of the zebrafish (Danio rerio). Int. J. Dev. Biol. 48: 217-231.

LUMSDEN, A.G.S. (1984) Tooth morphogenesis: contributions of the cranial neural crest cells in mammals. In: Tooth Morphogenesis and Differentiation (Belcour, A.B. and Ruch, J.-V., eds), pp: 29-40. Colloque Inserm, INSERM, Paris.

LUMSDEN, A.G.S. (1988) Spatial organization of the epithelium and the role of neural crest cells in the initiation of the mammalian tooth germ. Development, 103: 155-169.

MADERSON, P. (1972) When? Why? and How?: Some speculations on the evolution of the vertebrate integument. Amer. Zool., 12: 159-171.

MATSUMOTO, J., LYNCH, T.J., GRABOWSKI, S., RICHARDS, C.M., LO, S.M., CLARK, C., KERN, D., TAYLOR, J.D. and TCHEN, T.T. (1983) Fish tumor pigment cells: differentiation and comparison to their normal counterparts. $\mathrm{Am}$. Zool., 23: 569-580.

MCCRIMMON, H.R. and SWEE, U.B. (1967) Scale formation as related to growth and development of young carp, Cyprinus carpio L. J. Fish. Res. Board Can., 24: 47-51.

MEUNIER, F.J. (1983) Les tissus osseux des Ostéichthyens. Structure, genèse, croissance et évolution. Archives et Documentations, Micro-Edition, Institut d'Ethnologie, Museum National d'Histoire Naturelle, Paris, SN, 82-600-328, $200 \mathrm{p}$.

MONNOT, M.J., BABIN, P.J., POLEO, G., ANDRÉ, M., LAFOREST, L., BALLAGNY, C. and AKIMENKO, M.-A. (1999) Epidermal expression of apolipoprotein $E$ gene during fin and scale development and fin regeneration in zebrafish. Dev. Dyn., 214: 207-215.

NOHNO, T., KAWAKAMI, Y., OHUCHI, H., FUJIWARA, A., YOSHIOKA, H. and NOJI, S (1995) Involvement of the sonic hedgehog gene in chick feather formation. Biochem. Biophys. Res. Commun., 206: 33-39.

PERRIMON, N. (1994) The genetic basis of patterned baldness in Drosophila. Cell, 76: 781-784.

QUILHAC, A. and SIRE, J.-Y. (1998) Restoration of the subepidermal tissues and scale regeneration after wounding a cichlid fish, Hemichromis bimaculatus. J. Exp. Zool., 281: 305-327.

QUINT, E., SMITH, A., AVARON, F., LAFOREST, L., MILES, J., GAFFIELD, W. and AKIMENKO, M.A. (2002) Bone patter is altered in the regenerating zebrafish caudal fin after ectopic expression of sonic hedgehog and bmp2b or exposure to cyclopamine. Proc. Natl. Acad. Sci., USA, 99: 8713-8718.

REIF, W.-E. (1980a) Development of dentition and dermal skeleton in embryonic Scyliorhinus canicula. J. Morphol., 166: 275-288.

REIF, W.-E. (1980b) A model of morphogenetic processes in the dermal skeleton of elasmobranchs. Neues Jahrb. Geol. Paläontol., Abh., 159: 339-359.

REIF, W.-E. (1982) Evolution of dermal skeleton and dentition in Vertebrates. The odontode regulation theory. In: Evolutionary Biology (M.K. Hecht, B. Wallace and G.T. Prauce, eds), pp. 287-368. Plenum Press.

REIF, W.-E. and RICHTER, M. (2001) Revisiting the lepidomorial and odontode regulation theories of dermo-skeletal morphogenesis. Neues Jahr. Geol. Paläont., 219: $285-304$

RIDDLE, R.D., JOHNSON, R.L., LAUFER, E. and TABIN, C. (1993) Sonic hedgehog mediates the polarizing activity of the ZPA. Cell, 75: 1401-1416.

SCHULTZE, H.P. (1966) Morphologische und histologische Untersuchungen an Schuppen mesozoischer Actinopterygier. Ubergang von Ganoid-zu RundSchuppen. Neue Jahrb. Geol. Paläontol., 126: 232-314.
SCHULTZE, H.P. (1996) The scales of Mesozoic actinopterygians. Inr. Mesozoic Fishes Systematic and Palaeoecology (Arratia, G. and Viohl, G., eds), pp. 8393. Verlag Dr. F. Pfeil, München.

SCHULTZE, H.P., and BARDACK, D. (1987) Diversity and size changes in palaeonisciform fishes (Actinopterygii, Pisces) from the Pennsylvanian Mazon Creek Fauna, Illinois, U.S.A. J. Vert. Paleontol., 7: 1-23.

SENGEL, P. (1976) Morphogenesis of the Skin. 277 p. Cambridge University Press, Cambridge, London, New York, Melbourne.

SIRE, J.-Y. (1985) Fibres d'ancrage et couche limitante externe à la surface des écailles du Cichlidae Hemichromis bimaculatus (Téléostéen, Perciforme): données ultrastructurales. Ann. Sci. Nat., Zool., Paris, 13: 163-180.

SIRE, J.-Y. (1987) Structure, formation et régénération des écailles d'un poisson téléostéen, Hemichromis bimaculatus(Perciforme, Cichlidé). Thèse de Doctorat ès-Sciences, Université Paris 7.

SIRE, J.-Y. (1988) Evidence that mineralised spherules are involved in the formation of the superficial layer of the elasmoid scale in the cichlids Hemichromis bimaculatus and Cichlasoma octofasciatum (Pisces, Teleostei): an epidermal active participation? Cell Tissue Res., 253: 165-172.

SIRE, J.-Y. (1989) The same cell lineage is involved in scale formation and regeneration in the teleost fish Hemichromis bimaculatus. Tissue Cell, 21: 447462.

SIRE, J.-Y. (1990) From ganoid to elasmoid scales in the actinopterygian fishes Neth. J. Zool., 40: 75-92.

SIRE, J.-Y. (1993) Development and fine structure of the bony scutes in Corydoras arcuatus (Siluriformes, Callichthyidae). J. Morphol., 215: 225-244.

SIRE, J.-Y. (2001) Teeth outside the mouth in teleost fishes. How to benefit from a developmental accident. Evol. Dev., 3: 104-108.

SIRE, J.-Y. and ARNULF, I. (1991) The pattern of squamation development in fishes. Jap. J. Ichthyol., 37: 137-143.

SIRE, J.-Y. and GÉRAUDIE, J. (1983) Fine structure of the developing scale in the cichlid Hemichromis bimaculatus (Pisces, Teleostei, Perciformes). Acta Zool., Stockh., 64: 1-8

SIRE, J.-Y. and GÉRAUDIE, J. (1984) Fine structure of the regenerating scales and their associated cells in the cichlid Hemichromis bimaculatus (Gill). Cell Tissue Res., 237:537-547.

SIRE, J.-Y. and HUYSSEUNE, A. (2003) Formation of skeletal and dental tissues in fish: A comparative and evolutionary approach. Biol. Rev., 78: 219-249.

SIRE, J.-Y., GÉRAUDIE, J., MEUNIER, F.J. and ZYLBERBERG, L. (1987) On the origin of the ganoine: histological and ultrastructural data on the experimental regeneration of the scales of Calamoichthys calabaricus (Osteichthyes, Brachyopterygii, Polypteridae). Amer. J. Anat., 180: 391-402.

SIRE, J.-Y., ALLIZARD, F., BABIAR, O., BOURGUIGNON, J. and QUILHAC, A (1997a) Scale development in zebrafish (Danio rerio). J. Anat., 190: 545-561.

SIRE, J.-Y., QUILHAC, A., BOURGUIGNON, J. and ALLIZARD, F. (1997b) Evidence for participation of the epidermis in the deposition of superficial layer of scales in zebrafish (Danio rerio): A SEM and TEM study. J. Morphol., 231: 161174.

SMITH, J.C. (1994) Hedgehog, the floor plate, and the zone of polarizing activity Cell, 76: 193-196.

THESLEFF, I. and SHARPE, P. (1997) Signalling networks regulating dental development. Mech. Dev., 67: 111-123.

THESLEFF, I. VAAHTOKARI, A. and PARTANEN, A.-M. (1995a) Regulation of organogenesis: Common molecular mechanisms regulating the development of teeth and other organs. Int. J. Dev. Biol., 39: 35-50.

THESLEFF, I., VAAHTOKARI, A., KETTUNEN, P., and ABERG, T. (1995b) Epithelial-mesenchymal signaling during tooth development. Connect. Tissue Res., 32: 9-15.

TOYOSAWA, S., O'HUIGIN, C., FIGUEROA, F., TICHY, H. and KLEIN, J. (1998) Identification and characterization of amelogenin genes in monotremes, reptiles, and amphibians. Proc. Natl. Acad. Sci. USA, 95: 13050-13061.

TURING, A.M. (1952) The chemical basis of morphogenesis. Proc. Roy. Soc. Lond $B, 237: 37-72$ 
VIALLET, J.P., PRIN, F., OLIVERA-MARTINEZI., HIRSINGER, E., POURQUIÉ, O. and DHOUAILLY, D. (1998) Chick Delta-1 gene expression and the formation of the feather primordium. Mech. Dev., 72: 159-168.

WATSON, D.M.S. (1937) The acanthodian fishes. Phil. Trans. Roy. Soc. Lond. B, 228: $49-146$.

WESTERFIELD, M. (1993) The Zebrafish Book. Eugene: University of Oregon Press.

WHITEAR, M. (1986) The skin of fishes including cyclostomes. Epidermis. Dermis. In: Biology of the Integument. 2. Vertebrates (Bereiter-Hahn, J., Matoltzy, A.G. and Richards, S., eds), pp. 8-64. Springer-Verlag, Heidelberg.

WILLIAMSON, W.C. (1849) On the microscopic structure of the scales and dermal teeth of some ganoid and placoid fish. Phil. Trans. Roy. Soc. Lond., 139: 435-475.
WOLPERT, L. (1998) Pattern formation in epithelial development: the vertebrate limb and feather bud spacing. Phil. Trans. Roy. Soc. Lond. B, 353: 871-875.

ZIDEK, J. (1985) Growth in Acanthodes (Acanthodii: Pisces): data and implications. Paläont. Zeitsch., 59: 147-166.

ZYLBERBERG, L., GÉRAUDIE, J., MEUNIER, F.J. and SIRE, J.-Y. (1992). Biomineralisation in the integumental skeleton of the living lower Vertebrates. In Bone - Bone Metabolism and Mineralisation, vol. 4 (Hall, B.K., ed.), pp. 171 224. CRC Press Inc.

ZYLBERBERG, L., SIRE, J.-Y., NANCI, A. (1997) Detection of amelogenin-like proteins in the ganoine of experimentally regenerating scales of Calamoichthys calabaricus, a primitive actinopterygian fish. Anat. Rec., 249: 86-95. 